\title{
Human Capital Management: An Emerging Human Resource Management Practice
}

\author{
Faryal Siddiqui \\ Department of Management Sciences, Abbasia Campus \\ The Islamia University of Bahawalpur, Punjab, Pakistan \\ E-mail: faryalsiddiqui_88@yahoo.com
}

Accepted: December 17, 2011 Published: February 3, 2012

Doi:10.5296/ijld.v2i1.1354ＵRL: http://dx.doi.org/10.5296/ijld.v2i1.1354

\begin{abstract}
:
The principal purport of this study is to explore and look for variety of aspects and the significance of human capital in today's hyper-competitive environment besides delve in to details for gaining more insights regarding the subject in focus i.e. human capital. The paper is an exploratory study, which by and large relies heavily on the analysis of available literature and model testing. Organizations have been persistently adverting fair amount of emphasis on human capital by taking necessary measures to develop a culture of knowledge sharing, retain highly competent employees to generate more innovative ideas with a view to achieve the competitive advantage for having an edge over contemporary organizations. Having set forth afore-said goals; top management of dynamic organizations more often than not encourage their employees to actively participate in the knowledge sharing practices. The inference is that human capital by all means is positively related to the organizational productivity since implementation of the creative ideas and innovations do improve the organizational outcomes. As a result of intellectual capital employees tend to become loyal and passionate about their work and devote their talents to the best of their potential to achieve the all important competitive advantage.
\end{abstract}

Key words: Human Capital, Organizational Performance, Competent Employees, Intellectual Capital, Social Capital, Competitive Advantage.

\section{Introduction}

Currently in the hypercompetitive and dynamic environment; the organizations in general provide attractions for the knowledge their workers possess and gain so as to stay alive and excel. Now-a-days competitive advantage can only be gained with the help of the knowledge their workers have among them. Conventional ways of gaining the competitive edge (natural, 
financial and achieving the economies of scale); therefore, have become obsolete now (Burke, 2005). The job demands also have increased manifold now-a-days as such employees with versatile and dynamic skills only can cater for the job requirements. There is intense emphasis today on capabilities of employees and organizations thus are moving towards learning organizations in which the employees are empowered and are provided with opportunities to develop and enhance their careers. In order to make the employees more efficient; the organizations provide them with appropriate resources and afford training sessions. (Kazlauskait \& Bučiūnien, 2008).

Workers with their knowledge bring creative and innovative ideas that in turn increase worth of the organization. The value is added in the intangible resources such as patents, reputation of an organization and also to the competence of employees (Sveiby, 1997). This added value will increase the organizational productivity and also improve the performances of employees (Bontis et al., 2000; Chen et al., 2005; Youndt and Snell, 2004). These workers with knowledge are also referred to as the intellectual capital. There are the three elements of intellectual capital: human capital, relational capital and structural capital (Bontis, 1996; Edvinsson and Malone, 1997; Marr, 2005; Roos et al., 1997; Stewart, 1997).

Organizational culture plays a significant role in knowledge practices because it is the norms and values of an organization that alter the personnel's attitude and action. Organizations motivate their workforce to conduct brainstorming sessions through which they can generate the innovative ideas and suggest the alternate solutions to the problems. Top management encourages the employees to share their experiences and awareness. The knowledge thus generated through collective wisdom can lead towards the competitive advantage (Floyd \& Lane, 2000).

\section{Literature Review}

Human capital represents various features and aspects of organizational employees. These features include but not restricted to their competencies, procedural knowledge and particular individual's characteristics like mental ability, zeal and enthusiasm, opinion, consistency, dedication, loyalty, innovativeness, ingenuity, ability to work in team and proficiency to attain organizational coveted objective (Fitz-enz, 2000).

As defined by Baron and Armstrong (2007); human capital management is related with acquiring the information which let management know about its different policies albeit policy regarding its finance, procedures and also about how their human resource do in fact add value to the organization.

The basic feature of human capital is that how the organization treats its employees as the most valuable resource. Furthermore by utilizing the workforce efficiently the organization can attain the competitive edge. Human capital management is a link between workforce and organizational planning (Kearns, 2005). The word human capital was instigated by Schultz in 1961 but this term was explained later in 1981 as all the capabilities of an individual must be taken into consideration whether these competencies are inherent or learned. Those characteristics of a person that create or add value to the organizational operations is regarded as human capital. 
- Another comprehensive definition given by Bontis et al (1999); human capital indicate those reasons, which bring the individuals together in the organization, where they share their understandings of different aspects, experiences and awareness by which they make firm different from its competitors. For this the organization must possess such human resource that are motivated towards learning, adjust themselves in the dynamic environment, have creative and innovative ideas and with the right supervision they make organization able to compete with their benchmarks. Following are some key elements of human capital._Intellectual Capital:

The most significant element of human capital is intellectual capital. It refers to the creative and innovative brainpower existing within the organization. The human resource is an intellectual capital of any organization so the organization utilizes its intangible asset and other financial or physical resource that makes the firm worthwhile (Bontis, 1998).

\section{- Social Capital:}

In this component knowledge is acquired from the collective wisdom. It can be from outside or within the organization. Social capital is explained as those factors that allow the people to work collectively to fulfill the mutual goals. Factors include mutual trust, values and certain standards (Putnam, 1996). However, the social capital can be created and modified according to the circumstances with the passage of time (Bontis et al, 1999.

\section{Organizational Capital:}

Organizational capitals include the confidential information that the organizational holds it is data bank (Youndt, 2000). Organizational capital is also known as the structural capital (Edvinson \& Malone, 1997).

\section{List of human capital characteristics}

\begin{tabular}{|c|c|c|c|c|c|}
\hline 1. & Know-how & 11. & Union activity & 21. & Efficiency ratios \\
\hline 2. & Education & 12. & Employee number & 22. & Stability ratios \\
\hline 3. & $\begin{array}{l}\text { Vocational } \\
\text { qualifications }\end{array}$ & 13. & Employee thanked & & \\
\hline 4. & $\begin{array}{l}\text { Employee involvement } \\
\text { in community }\end{array}$ & 14. & Employee featured & & \\
\hline 5. & Career development & 15. & $\begin{array}{l}\text { Executive } \\
\text { compensation plan }\end{array}$ & & \\
\hline 6. & Entrepreneurial spirit & 16. & $\begin{array}{l}\text { Employee } \\
\text { compensation plan }\end{array}$ & & \\
\hline 7. & Training programs & 17. & Employee benefits & & \\
\hline 8. & $\begin{array}{l}\text { Equity issue: race, } \\
\text { gender and religion }\end{array}$ & 18. & $\begin{array}{l}\text { Employee share option } \\
\text { scheme }\end{array}$ & & \\
\hline 9. & $\begin{array}{l}\text { Equity issue: disable } \\
\text { issues }\end{array}$ & 19. & $\begin{array}{l}\text { Employee share option } \\
\text { scheme }\end{array}$ & & \\
\hline 10. & Employment safety & 20. & Growth/renewal ratios: & & \\
\hline
\end{tabular}


average professional

experience

Source: Adapted from Abeysekera \& Guthrie, 2004

\section{Human resource management (HRM) and Human capital management (HCM)}

Human capital management requires capable employees whose competence is above board and are highly proficient in performance of their work. These people introduce creative, innovative ideas and make the organization different from its competitors. Human capital management is related to employee's commitment, retention, talent management, learning and development of personnel. To manage highly competent employees has become very important in order to survive in today's dynamic and extraordinary competitive environment (Huselid, 1995 and Youndt et al., 1996). There are three elements of human capital management that boost-up the effect of human resource management:

- Employee dedication

- Mutual trust between employer and employee.

- Norms, values of organization and also the top management behavior (Tower, 1994).

Significantly human resource management is concerned with the demand and supply of the workforce but understanding of knowledge and skills are also amongst the requisites for the organization to achieve its goals and objectives. Human resource management is pertinent to the day to day issues of the workforce. It attracts and enables to manage the performance of the employees to accomplish the organizational objectives. The aim of human resource management is to align the actions of employees with the organizational goals (Rondeau \& Wagar, 2002 and Laursen \& Foss, 2003).

\section{Significance of Human Capital Management}

It is very important for any organization to attract, fascinate and retain highly capable employees. Mostly, the organizations concentrate on their physical and financial resources but relatively do give a considerable amount of time on its personnel's. However, the organizational employees have formal reporting relationship and chain of command. There must be pragmatic policy to motivate the employees and in turn give them the ex-gratia or right benefits. By motivating their employee at the right time; the organization can easily attain the competitive advantage (Edward \& Lawler, 2009).

However, keeping highly capable and competent employee is always challenging proposition rather not an easy task. This can only be made possible when the Manager or Supervisors provide proper guidance to the employees. Concisely; provide them with the proper feedback on their performance and at the same time award them with appropriate, righteous and proper compensations and benefits in recognition of thereof. People ought to be motivated so that they become faithful so that their loyalty to the organization is obvious 


\section{Macrothink Institute ${ }^{T M}$}

and they sincerely devote their full energy, expertise and talent to complete their given tasks with consummate skill.

Organization basically requires three things to manage its highly talented workforce ( Edward \& Lawler, 2009) as follows:

$>$ Top management must have proper perception, knowledge and skills to manage its employees and also be capable to handle other organizational matters (Edward \& Lawler, 2009).

$>$ There must be effective leadership within the organization and it is incumbent on the top management to work on its employees in order to inculcate and develop leadership skills (Edward \& Lawler, 2009).

$>$ The workforce must be highly talented having fair amount of awareness of the business operations and must be capable as to how the personnel can be attracted and managed. (Edward \& Lawler, 2009).

In human capital management; resource-based view is of paramount importance because it invariably elaborates how organizational resources help organization to make them uniquely different from its competitors. Resource-based view transpires that organizational personnel's are the most worthwhile asset of an organization and it is hard for the competitors to replicate such human resource (Barney, 1991; Grant, 1991; Peteraf, 1993; Teece et al., 1997). Human capital is consisting of scarce and worthwhile resource that will lead the organization to achieve the competitive edge (Hsu, 2008).

\section{Human Capital Framework}

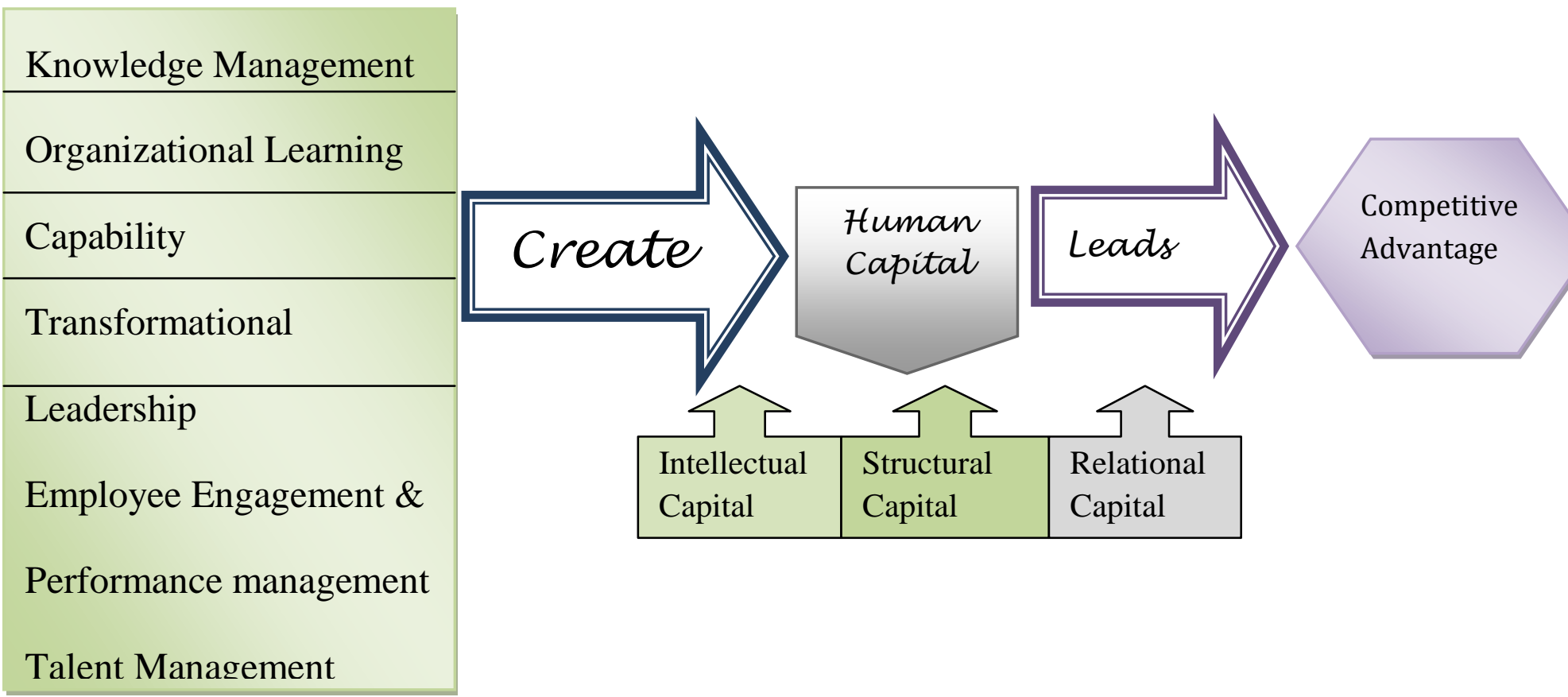




\section{Discussion}

Employee dedication and loyalty is very important in today's active, dynamic and continuously changing environment whereas this aspect is very significant in order to ensure survival in a turbulent environment. Furthermore, in today's highly competitive environment human capital, intellectual capital and knowledge management practices are very much essential. These practices make the organization different from others and help them to achieve competitive advantage (Bontis, 2002; Choo and Bontis, 2002).

Following are the few aspects of human capital:

\section{Knowledge Management and Human Capital Management:}

Knowledge management is an institutionalized erudition, which enhances the organizational productivity and also brings about innovative and creative ideas through collective wisdom (Stankosky, 2007). Knowledge management is meaningfully significant because it supports the organizational objective in a way that it determines what special expertise the organization requires. Following this the logical sequence is: (a) find out the people having that special expertise, (b) recruit them and create intellectual capital to have more unique suggestions. Below are some kinds of intellectual capital (Jackson, 2007):

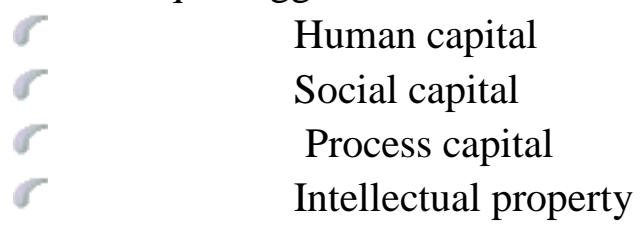

In an active and continuously changing environment organization maintain a workforce who can adapt themselves to the requisites of dynamic environment and sustain the long-term survival of a firm by making organization different from its competitors. Companies value their intangible asset for the creative and innovative plans (Amit \& Schoemaker, 1993).

All organizations albeit small or large; are engaged in the knowledge management practices for their organizational success. It is very important for an organization to develop a culture that influences the personnel to share the experiences with each other. Open communication and flat organizations will let the individuals to share their expertise easily and elaborately with each other (Sandia \& Smith, 1998).

Personnel's are motivated to take part in internal as well as external environment to update their knowledge and skills. The participation of workforce in the external environment will increase the worth of products and services. Information gained through the social relationship will let the organization improve their ways of doing the job. Sharing of more knowledge among the employees will end up in enhanced organizational productivity. In this process the human capital is generated when the employees had shared their experiences and learning with each other. The competitive edge can only be attained when 


\section{Macrothink Institute ${ }^{\text {TM }}$}

the organization does have know-how and perception of its competitors. When the organizational structure is codified it will result in visible improvement in the quality of decisions taken by the organization (Filius et al, 2000).

\section{Human capital and organizational learning capability:}

Human capital is a valuable and intelligible resource of an organization through which the organizational long-term survival can be foreseen and achieved. Prudent management of human resource in an effective manner shall enable the organization not only to sustain its long-term survival but also will increase its alert responsiveness to work in the dynamic environment (Barney \& Wright, 1998).

Organizational learning capability makes the employees unparalleled and inimitable resource that obviously makes the task difficult for the competitors to emulate in creating the identical resource. Human capital; nevertheless, is directly coupled with organizational learning capability since it facilitates to explore the specific ways of doing the tasks and also enables these to be recorded, documented in the organizational data bases; therefore, it connotes to become the ruling criteria / bench mark to perform the job. It per se helps the organization to develop a learning culture within the organization. This learning culture furthers the employees to acquire the dynamic expertise (Collins \& Smith, 2006).

Organizational learning capability; among others, have aspects of tangible bearing (Jerez-Gomez et al, 2005) as below:

r Managerial commitment.

System perspective.

$\checkmark$ Openness and experimentation.

Knowledge transfer and integration.

Organizational learning capability is further divided into two aspects:

1. Absorptive Capability and

2. Transformative Capability.

"Absorptive Capability" is exploration ability, which includes the organizational competence in developing the relations outside the organization and discovers the information that is appropriate to the organizational culture (Cohen \& Levinthal, 1990).

Additionally it also uncovers the ways for further advancements whereas the "Transformative capability" is related to the implementation of the acquired knowledge. It is the organizational ability to prioritize their task and plan which information is to be used as first preference. The organization must implement ramifications of its knowledge to the particular jobs to gain the competitive advantage. This capability in particular results in augmenting the organizational responsiveness to work in the impelling environment.

(Kought \& Zander, 1992). 


\section{Intellectual Capital:}

Intellectual capital is an organizational competence, which is implemented to achieve the competitive edge and comprises the human capital, the structural capital and the relation capital. The human capital by and large is related to the competencies and experience, the structural capital on the other hand is associated with the procedural knowledge and the data banks of an organization and the last one i.e. relational capital; however, contains the organizational social linkages both inside and outside the organization (Youndt et al, 2004).

There are two elements of structural capital viz.

Objectified knowledge

Collective knowledge.

Objectified refers to the information communicated in-house within the organization. It can be in the form of copyrights; information stored in the different soft wares, conveyed information from the top management and shared among the employees. The collective knowledge on the other hand is related with the information acquired from the organizational social networks and this knowledge is imbued in the organization culture and procedures (Longo et al, 2009).

Two of the most significant human resource functions having a positive impact on intellectual capital are:

Communication.

Employee perception of the company's vision and strategic intent.

Communication includes both upward and downward flow of communication. The purpose of the communication by its implication is that the top management of the organization if intends to know about the employee's individual and career related anticipations gets into a position where the same can implement the required practices in order to cater for its personnel's needs (Longo \& Mura, 2010).

The second function of human resource is the employee's perception of the company vision means that the organizations advancement is communicated to the employees from time to time. It is obligatory for the workforce of the organization to have of the requisite knowledge of organizational current status. It is very important because this will help the employee to strive in line with achievement of the organizational objective. Affording the employees with the appropriate training sessions will lead to achieve its objective more effectively and efficiently. When the information is communicated and is shared across the whole organization it will lead the firm towards the organizational learning. However, where the employees have the leverage to undertake their work, they vicariously are thus encouraged to commit the mistakes because the top management thinks that personnel's will learn more by doing mistakes. Organizational learning will also benefit the organization in generating the human capital within the organization (Schliemann, 2006). 


\section{Transformational leadership:}

In today's dynamic and intensely competitive environment it is pivotal for the organization to be unique from the competitors in order to survive and sustain its lively entity. Obviously there are certain requirements for achieving the competitive edge. These elements are the organization's norms and values, its human capital, governance and its information technology. The organization must have these factors in a unique manner in order to make its organization different from its competitors (Barney, 1986; Powell \& Dent-Micallef, 1997; Wright et al, 1994; Hitt et al., 1998).

These elements will also generate the intellectual capital, which includes both the human capital and the structural capital. Basically it is the human resource of an organization, which leads towards the competitive advantage because the human resource is intangible resource of an organization and also it is difficult for its competitors to generate the kind of employees at par in competence in their organizations (Prahalad \& Hamel 1990; Barnet 1991).

Transformational leadership is defined by Koehler and Pankowski (1997) as it is a series of actions that motivate the employees to work in a dynamic environment, to enhance their productivity and also make their process better to achieve the competitive advantage. Transformational leader makes the employees empowered and autonomous in order to have more creative and innovative ideas. Transformational leaders also act as a coach and mentors of their employees, this makes employees zealously motivated and they devote their energies to the capacity in order to complete their requisite tasks ( $Y u k l$, 2006).

Interim leadership described by Weingarten (2003), is a method by which the highly competent employees of an organization fill the top management positions for a short period of time whereby the interim leadership exhibits the progress and growth of an organization. The aim of this interim leadership is to gain the competitive edge through its employees. Here the employees will not actively participate in the long term decision of an organization. This will benefit the employees in their professional lives besides making the organization unique (Goler, 2003).

\section{Employee Engagement and Performance Management:}

Employee engagement refers to the dedication and loyalty of an individual towards its job (Schaufeli \& Salanova, 2007). It follows that not only an employee is physically providing its services to the organization but also he is very passionate about his job (Kahn, 1990). However, employee's engagement is positively related with the organizational productivity. The appropriate resources available to the employees to complete their work are of immense significance because this will make the organizational employees more enthusiastic about their entrusted task and also make them dedicated, loyal to the firm. It will also provide opportunity to the employee for their further development and advancements in careers, which will ultimately make the organization different from its competitors. Resources enable and facilitate the employees 
to fulfill the requirements of job and to work in the turbulent environment (Bakker \& Demerouti, 2007, 2008).

However, in today's computerized environment, all the organizations are in pursuit of working to generate the human capital within their organizations. Now-a-days it has become very essential to have workforce, which leads the organization towards achieving competitive advantage (Hayes \& Schaefer, 1999; Murphy, 1985; Lev, 2001). Organizations are working on human capital to have creative and innovative ideas to improve the practices they are implementing within the organization. Leading organizations of the world are more dedicated towards their workforce because they think that their staff is their most valuable and important asset. As such, providing them with appropriate training sessions, proper compensations and benefits will make their organization unique (Lajili \& Zeghal, 2006).

\section{Talent management:}

Talent management implies: appositely finding the most suitable incumbent for the organization (Jackson \& Schuler, 1990). It is also defined by Roth well, 1994 as a methodology by which we make sure that the highly competent employees will get the opportunity to further develop their careers by fulfilling the top management positions. Talent management is also known as succession of planning and human resource planning. Here the organization makes sure that every employee will get the proper and sufficient opportunities and make the best of it. The most important aspect of talent management is that the organization must be aware of their personnel's talent, traits, expertise and the level of competence. Talent management is succeeded by the second most significant element, which is human resource planning. Organizations usually make lists of the competencies they mostly require. This will help them to find out the individual with appropriate skills. Talent management involves high performing employees and highly capable individuals. Combining highly capable and competent employees will help the organizations to do succession planning successfully (Axelrod, Han dfieki-Jones \& Michaels, 2002; Michaels, Hadfield-Jones \& Axelrod, 2001).

\section{Conclusion:}

In today's knowledge-based economy greater emphasis is adverted to human capital. To survive in the dynamic environment and to achieve the competitive advantage; human capital is of immense priority thus has become very important. Organizations are much concerned with the human capital because they think they can only achieve the competitive advantage with the effective utilization of its human resource. Because of the fact that it is only the workforce of an organization that exclusively and entirely can make it different from its competitors and also it is hard for the competitors to duplicate the same workforce at their respective ends. Now-a-days the organizations are struggling to improve the performance of employees by effectively implementing their human resource practices. Human capital will lead the organizations towards better decision making, extensively effective communication within the organization and generate creative and 


\section{Macrothink

innovative ideas. It is also ensured that every individual of an organization will get an opportunity to utilize his capacity to the full potential. Given the dissertation as above it can plainly be concluded that Human capital management can only be successful when the organizations are fully prepared to give significant attention towards adapt best knowledge management practices. 


\section{References}

1 Armstrong, M. (2010). Armstrong's Essential Human Resource Management Practice. India: Kogan Page limited

2 Abeysekera, I., \& Guthrie, J. (2004). Human capital reporting in a developing nation. The British Accounting Review 36 (2004), 251-268

3 Axelrod, B., Hadfield-Jones., and Michaels, E. (2002). A new game plan for C players. Harvard Business Review 80(1), 80-88

4 Baron, A., \& Armstrong, M. (2007). Human Capital Management: Achieving added value through people. London: Kogan page

5 Barney, J. B., and Wright, P. M. (1998). On becoming a strategic player: the role of human resources in gaining competitive advantage. Human Resource Management 37 (1), $31-46$

6 Bontis, N., Dragonetti, N. C., Jacobsen, K., and Roos, G. (1999). The knowledge toolbox: a review of the tool available to measure and manage intangible resources. European Management Journal 17(4), 391-402

7 Bontis, N. (1998). Intellectual capital: an exploratory study that develops measures and models, Management Decision. 36 (2), 63-76

8 Barney, J.B. (1986). Organizational Culture: Can It Be a Source of Sustained Competitive Advantage?. The Academy of Management Review 11, 656-665

9 Barney, J. B. (1991). Firm resource and sustained competitive advantage. Journal of Management 17, 99-120

10 Bakker, A. B., and Demerouti, E. (2007). The job demands-resources model: State of art. Journal of Managerial Psychology 22, 309-328

11 Bakker, A. B., and Demerouti, E. (2008). Towards a model of work engagement. Career Development International 13, 209-223

12 Bontis, N. (2002). World Congress of Intellectual Capital Readings, Butterworth-Heinemann KMCL Press, Boston.MA

13 Bontis, N., Keow, W.C.C. and Richardson, S. (2000). Intellectual Capital and Business performance in Malaysian Industries. Journal of Intellectual capital 1(1), 85-100

14 Burke, R. J. (2005). Reinventing Human Resource Management: Challenges and New Directions. London: Rout ledge

15 Collins, C., and Smith, K. (2006). Knowledge exchange and combination: the role of human resource practices in the performance of high-technology firms. Academy of Management Journal 49(3), 544-60

16 Cohen, W. M., and Levinthal, D.A. (1990). Absorptive capacity: a new perspective on learning and innovation. Adm. Sci 35(1), 128-152

17 Choo, C.W. and Bontis, N. (2002). The Strategic Management of Intellectual Capital and Organizational Knowledge. New York: Oxford University

18 Hen, M. C., Cheng, S.J. and Hwang, Y. (2005). An empirical investigation of the relationship between intellectual capital and firms' market value and financial performance. Journal of Intellectual Capital 6(2), 159-76

19 Edvinson, L., \& Malone, M. S. (1997). Intellectual capital: Realizing your company’s true 
value by finding its hidden brainpower. New York: Harper Business

20 Edward, E., \& Lawler, III. (2009). Make human capital a source of competitive advantage. Organizational Dynamics 38 (1), 1-7

21 Filius, R., De Jong, J. A. and Roelofs, E. C.(2000). Knowledge management in HRD office: a comparison of three cases. Journal of Management Information System 18(1), 185-214

22 Floyd, S. W., and Lame, P. J. (2000). Strategizing throughout the organization: Managing role conflict in strategic renewal. Academy of Management Review, 25(1), 154-177

23 Goler, R. I. (2003). Making the Most of the Internal Interim Directorship. Journal for Nonprofit Management 7, 56-66

24 Jackson, P. (2007). Knowledge Asset Management: A system approach for human capital management. The journal of information and knowledge management systems 37 (4), 399-403

25 Jerez-Gomez, P., Cespedes-Lorente, J., and Valle-Cabrera, R. (2005a). Organizational learning capability: a proposal of measurement. Journal of Business Research 58

(6), $715-25$

26 Hsu, C. I. (2007). Knowledge sharing practices as a facilitating factor for improving organizational performance through human capital: A preliminary test. Expert System with Application 35 (2008), 1316-1326

27 Hitt, M. A., Keats, B. W., and DeMarie, S. M. (1998). Navigating in the New Competitive Landscape: Building Strategic Flexibility and Competitive Advantage in the 21st Century. Academy of Management Executive 12, 22-42

28 Hayes, R. M., Schaefer, S. (1999). How much are difference in managerial ability worth? Journal of Accounting and Economics 27, 125-148

29 Kought, B., and Zander, U. (1992). Knowledge of the firm, a combinative capabilities and the replication of technology. Organ. Sci 3(3), 383-397

30 Koehler, J. W., and Pankowski, J. M. (1997). Transformational Leadership in Government Florida: St. Lucie Press

31 Kahn, W. A. (1992). To be full there: Psychology presence at work. Human Relations 45, 321-349

32 Kazlauskait, R., and Bucluniebe, I. (2008). The Role of human Resources and their Management in the Establishment of Sustained Competitive Advantage. Engineering Economics 5(60), 78-84

33 Laursen, K. \& Foss, J. N. (2003). Human resource management practices, Complementaries and the impact on innovation performance. Cambridge Journal of Economics 27 (2003), 243-264

34 Longo, M., Marini, M., and Mura, M. (2009). The effect of intellectual capital attributes on organizational performance. The case of Bologna opera house. Knowledge management Research and practices 7(4), 365-376

35 Longo, M., and Mura, M. (2010). The effect of intellectual capital on employees' satisfaction and retention. Information \& management, 1-30

36 Lev, B. (2001). Intangibles: Management, Measurement and Reporting. Washington, DC: Brookings Institution Press 
37 Marr, B. (2005). What is intellectual Capital? A perspective on Intellectual Capital: Multidisciplinary Insight into Management, Measurement and reporting, Elsevier, Oxford and Boston, MA

38 Michaels, E., Hand-field, J. H., and Axelrod, B. (2001). The war for talent. Water own, MA: Harvard Business School Press

39 Murphy, K. J. (1985). Corporate performance and managerial remuneration: an empirical analysis. Journal of Accounting and Economics 7, 11-42

40 Putnam, R. (1996). Who killed civic America? Prospect, March, 66-72

41 Powell, T. C., and Dent-Miscalled, A. (1997). Information Technology as competitive Advantage: The Role of Human Business, and Technology Resource. Strategic Management Journal 18, 375-405

42 Prahalad, C. K., and Hamel, G. (1990). The core competence of the corporation. Harvard Business Review 68, 78-91

43 Rondeau, V. K .,\& Wagar, H. T. (2002). Reducing the hospital workforce: What is the role of human resource management practices? , Hospital Topics 80 (2002), 12-18

44 Roth well, W. J. (1994). Effective succession planning: Ensuring leadership continuity and building talent from within. New York: Amazon

45 Roos, J., Roos, G., Dragonetti, N. C. and Edvinsson, L. (1997). Intellectual Capital: Navigating the new Business Landscape London: Macmillan Press Limited

46 Schultz, T. W. (1961). Investment in human capital. Economic Review 51, March, 1-17

47 Schultz, T. W. (1981). Investment in people: the economics of population quality, University of California, CA

48 Stankosky, M. (2007). Can you name your knowledge asset? Paper presented at European Conference on Knowledge Management, Consortia Escola Industrial de Barcelona, Spain

49 Schliemann, W. A. (2006). People equity: a new paradigm for measuring and managing human capital. Human resource planning. 29(2006), 34-44

50 Schaufeli, W. B., and Salanova, M. (2007). Work engagement: An emerging psychology concept and its implications for organization. In S. W. Gilliland, D.D. Steiner, and D. P. Skarlicki (Eds.) Managing social and ethical issues in organizations 135-177. Greenwich, CT: Information Age Publishing.

51 Sveiby, K. E. (1997). The new organization wealth: Managing and Measuring knowledge -based Assets, Beret-Koehler, San Francisco, CA

52 Stewart, T.A. (1997). Intellectual Capital: The new wealth of organization. New York: Currency Doubleday

53 Towers, W. G. (1994). Creating wealth in organizations: The role of strategic leadership. Academy of Management Executive 15(2001), 81-94

54 Wright, P. M., McWilliams, A. (1994). Human resource and sustained competitive advantage: a resource-based perspective International Journal of Human Resource Management 5, 301-242

55 Weingarten, S. F. (2003). Costs and benefits of interim managerial assignment in an academic library. Library Management 3, 132-142

56 Youndt, M. A. (2000). Human resource considerations and value creation: the mediating role of intellectual capital, paper delivered at National Conference of US Academy of 
Management, Toronto, August

57 Youndt, A. M., Subramaniam, A., and Snell, A. S. (2004). Intellectual capital profiles: An examination of investments and returns. Journal of Management Studies 41(2), 335-361

58 Youndt, M.A. and Snell, S. A. (2004). Human resource configurations, intellectual capital and organizational performance. Journal of managerial issues 16(3), 337-60

59 Yukl, G. (2006). Leadership in Organization. Upper Saddle River: Pearson-Practice Hall 